\title{
Use of Secondary Sewage Water as a Culture Medium for Chaetoceros gracilis and Thalassiosira Sp (Chrysophyceae) in Laboratory Conditions.
}

\author{
Rauquírio André Albuquerque Marinho da Costa; Maria Luise Koening* and Sílvio José \\ de Macêdo \\ Department of Oceanography of the Federal University of Pernambuco, Arquitetura Ave. $s / n^{o}$, Campus \\ Universitário, Cidade Universitária 50. 739-540 - Recife - Pernambuco - Brazil.
}

\begin{abstract}
Experiments were carried out in order to test the efficiency of additions of secondary sewage as a culture medium for Chaetoceros gracilis and Thalassiosira sp (Chrysophyceae) under laboratory conditions. These algae were cultivated in sea water with concentrations of 10\%, 20\%, 30\% and 40\% of wastewater. The results were compared with those obtained by the nutritive medium $f_{2}$ of Guillard (1975). The best results in terms of cellular densities were observed at 40\% additions. There were significant differences (significance levels of 5\%) between the nutritive medium $f_{2}$ and the $40 \%$ additions for both the species. Maximum cellular densities observed for all additions tested were, 4,125.00 $\times 10^{3} \mathrm{cell} / \mathrm{ml}$ for Chaetoceros gracilis on the ninth day and $834.00 \times 10^{3} \mathrm{cells} / \mathrm{ml}$ for Thalassiosira sp on the fifth day. Biomass was higher in the nutritive medium $f_{2}$ than in the other treatments, reaching average

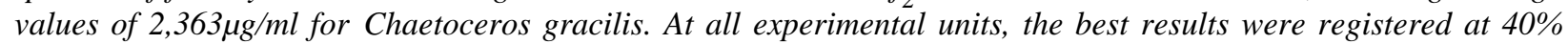
addition for Chaetoceros gracilis, where average values of $0.768 \mu \mathrm{g} / \mathrm{ml}$ were observed on the fifth day, and at $30 \%$ additions for Thalassiosira sp where $0.883 \mu \mathrm{g} / \mathrm{ml}$ were observed on the thirteenth day. It was concluded that secondary sewage could be used as a culture medium for the species tested here, after large scale tests.
\end{abstract}

Key words: Microalgae (Chrysophyceae), Culture, Secondary sewage

\section{INTRODUCTION}

The culture of microalgae begun at the end of the 19th century, becoming one of the great discoveries of our time for Botany and for Science in general. In the beginning, research was focused on creating a method of culture that could propitiate the survival and maintenance of clowns in the laboratory, to develop knowledge about the photosynthetic mechanisms of the organisms. After some time, especially after the Second World War, new and varied proposals surged for the utilization of phytoplanktonic organisms.

In Brazil, even though the culture of microalgae is recent, its activity expanded in parallel with the development of aquaculture. The necessity of a great supply of microalgae for the nourishment, direct or indirect, of various larvae stages of cultivable organisms of high economic value, generated an intensification of studies concerning the development of alternative mediums to reduce the costs of natural and artificial mediums previously in use, which were expensive due to the use of chemical substances of high commercial value.

Data obtained about the studies of the effects of urban and industrial wastewater additions on the phytoplanktonic populations of coastal regions (Taslakian \& Hardy, 1976) revealed an interest in specialists of phytoplankton, concerning the use of raw sewage water at different treatment stages, as a source of nutrients for the intensive culture of microalgae.

Some researchers studied the possible use of mixtures of wastewater with marine water, for the mixed culture of some microalgal species (Dustan \& Menzel, 1971; Dustan \& Tenore, 1972; Goldman \& Stanley, 1974).

\footnotetext{
* Author for correspondence
} 
In Brazil, only a few preliminary studies were carried out on the usage of untreated municipal sewage water for the culture of microalgae (Yoneshigue-Braga et al., 1977; Brazil-Lima \& Aidar, 1996), being this a pioneering study for the Northeast region of Brazil. The study's objective is to test the efficiency of various secondary wastewater additions, on the monospecific culture of Chaetoceros gracilis and Thalassiosira sp, species which are commonly utilized as alimentary diet for organisms raised in this region's aquaculture.

The study focuses on aspects such as cellular density and microalgae biomass, as well as on the comparison of the results with those obtained through the use of the medium $\mathrm{f}_{2}$ (Guillard, 1975).

\section{MATERIALS AND METHODS}

Experiments for Chaetoceros gracilis were designated as follows:

$\mathrm{Cg} 0$ and $\mathrm{Cg} 00^{\prime}$ - filtered and autoclaved sea water; $\mathrm{Cgl}$ and $\mathrm{Cgl}$ '- filtered and autoclaved sea water with the addition of the medium $\mathrm{f}_{2}$ (Guillard, 1975); Cg10 and Cg10'- filtered and autoclaved sea water, with $10 \%$ of secondary treated waste water; $\mathrm{Cg} 20$ and $\mathrm{Cg} 20$ '- filtered and autoclaved sea water, with $20 \%$ of secondary treated wastewater; $\mathrm{Cg} 30$ and $\mathrm{Cg} 30^{\prime}$ - filtered and autoclaved sea water, with $30 \%$ of secondary treated wastewater; $\mathrm{Cg} 40$ and $\mathrm{Cg} 40$ '- filtered and autoclaved sea water, with $40 \%$ of secondary treated wastewater.

For Thalassiosira sp, the same denomination was used, with the replacement of $\mathrm{Cg}$ by Th.

The salinity of the quotas and the replicas tested after the filtration in "cuno" and before the autoclaving process were adjusted at $30 \%$ o by freezing method to avoid errors of interpretation. The salinity of all the experimental units and concurrent replicas were determined by the Mohr-Knudsen method (Strickland \& Parsons, 1972).

The initial volume of each experimental unit and of their replicas was $700 \mathrm{ml}$, to which an unialgal clone of $60 \mathrm{ml}$, from each microalgae used, was added according to the respective bioassay.
Water used throughout the course of the bioassays was first filtered using Whatman filters, then in "cuno" filters with an aperture of 5 and $1 \mu \mathrm{m}$, and later autoclaved (45 minutes, one atmospheric pressure). The wastewater, was filtered using Whatman filters $(15 \mathrm{~cm})$ before passing through the same humid sterilization process.

The tested bioassays were maintained at a constant temperature of $22 \pm 1^{\circ} \mathrm{C}$, and exposed to a photoperiod of 24 hours under fluorescent lights of 20 Watts.

The analysis of the concentrations of nutrient salts, were carried out in the beginning, on the seventh day and at the end of the testing according to method described by (Strickland \& Parsons, 1972; Grasshoff et al., 1983), through the collection of subsamples of $150 \mathrm{ml}$, which were kept frozen.

Both the results of the concentrations of nutrient salts and of the hydrogenionic potential were expressed in average values.

Aliquotes of $5 \mathrm{ml}$, were collected daily for the determination of the microalgae density in cell $/ \mathrm{ml}$. For this, the Neubauer chamber was used, counting the number of cells with the help of the binocular optic microscope Bausch \& Lomb, and expressing them in average values of cells/ml.

The daily average growth rates were measured during the exponencial phases of each bioassay through the formula: $\mathbf{k}=\left[\mathbf{3 , 3 3 2} /\left(\mathbf{t}_{2}-\right.\right.$ $\left.\left.\mathbf{t}_{1}\right)\right] .\left(\log \mathbf{N}_{2} / \mathbf{N}_{1}\right)$, (Guillard, 1973), in which:

$\mathbf{k}$ - daily growth rate; $\mathbf{t}$ - time; $\mathbf{N}$ - number of cells.

The average chlorophyll- $a$ concentrations were measured through the filtration of subsamples of 2.5 to $10 \mathrm{ml}$ of each unit tested and respective replica, in intervals of 4 days, totaling 5 filtrations throughout the bioassays for each control and tested additions.

For the determination of the chlorophyll- $a$ total concentrations, the spectrophotometric analysis method was used (Creitz \& Richards, 1955; UNESCO, 1966). The filtration was carried out in Millipore Ha filters, with a $25 \mathrm{~mm}$ diameter and $0.45 \mu \mathrm{m}$ porosity. After the filtration, the 
conventional stages of the method were followed, carrying out the readings in a Micronal spectrophotometer, in wavelengths of 630, 645, 665 and 750mm.

The calculations of the chlorophyll- $a$ concentrations were carried out according to the formula of (Parsons \& Strickland 1963):

$$
\begin{aligned}
& \mu \mathrm{g} / \mathrm{ml}=\frac{11.6 . \mathrm{D}_{665}-\left(1.31 \cdot \mathrm{D}_{645}+0.14 . \mathrm{D}_{630}+\mathrm{D}_{750}\right)}{\mathrm{V} . \mathrm{L}} \cdot \mathrm{v} \\
& \mathrm{V} \text { - acetone volume } \\
& \mathrm{V} \text { - sample volume filtered } \\
& \text { D- optical density at the different wavelengths } \\
& \text { L- optical way of the cuvette }
\end{aligned}
$$

\section{Statistic analysis of the data of cellular density and biomass}

The formula of adjustment of the number of cells $/ \mathrm{ml}$ in relation to time of culture of the two tested species, using sea water (experimental unit 0 ), the nutritive medium $\mathrm{f}$, and additions of $10 \%, 20 \%, 30 \%$ and $40 \%$ of wastewater was the following:

$\mathbf{N}^{\mathbf{0}}$ of cells $=\beta_{\mathbf{0}} \mathbf{t} \mathrm{e}^{-\beta 1 t}+\varepsilon_{\mathrm{I}}($ Santos, 1995), where: $\mathbf{t}$ - time of culture (days), $\boldsymbol{\beta}_{\mathbf{0}} \mathbf{e} \boldsymbol{\beta}_{1}$ - parameters of the model; $\boldsymbol{\varepsilon}_{\mathrm{I}}$ - error associated to each observation.

To compare the microalgae's growth model the following equation was used:

$W=\left(n_{1}+n_{2}\right) \cdot L N \quad\left(S_{1} R_{1,2} \quad /\left(n_{1}+n_{2}\right)\right)-n_{1} \cdot L N$ $\left(\mathrm{SQR}_{\mathbf{1}} / \mathbf{n}_{\mathbf{1}}\right)-\mathbf{n}_{\mathbf{2}} \cdot \mathbf{L N}\left(\mathbf{S Q R}_{\mathbf{2}} / \mathbf{n}_{\mathbf{2}}\right)$ where:

$\mathbf{W}$ - statistic to be compared with $2 ; \mathbf{n}_{1}$ - number of data from sample $1 ; \mathbf{n}_{2}$ - number of data from sample 2; $\mathbf{S Q R}_{1,2^{-}}$sum of the squares of the residues of samples 1 and 2; $\mathbf{S Q R}_{1}$ - sum of the squares of the residues of sample $1 ; \mathbf{S Q R}_{2}$ - sum of the squares of the residues of sample 2 .

The comparative statistic "W" was analysed to the confidence level of $5 \% \quad(\mathrm{P}<0.05)$. The computer program CAJUS (Santos, 1995) was used for the adjustment of the growth curves. The same method described for population density (cells/ml) was used for the statistical analysis of the biomass.

\section{RESULTS AND DISCUSSION}

\section{Nutrient salts}

The results concerned with the nutrient concentrations (nitrite-N, nitrate-N, silicate-Si and phosphate-P) presented higher values on the first day and lower on the seventh day of experiment. On the last day, higher values than the ones registered in the seventh day were observed in most of the experiments. This was due to the non-axenic cultures, which propitiated the nutrient remineralization by the bacteria.

The nitrite- $\mathrm{N}$ maximum $\left(8.954 \mu\right.$ moles. $1^{-1}$, in the experimental unit Th40) and minimum (0.016 umoles. $1^{-1}$, in the experimental units Th30 and Th40) concentrations were registered on the first and seventh days of culture, respectively. For nitrate-N, the maximum concentration obtained was $14.293 \mu$ moles. $1^{-1}$ on the first day (experimental unit $\mathrm{Cg} 40$ ), while the minimum was $0.485 \mu$ moles. $1^{-1}$ on the seventh day of culture (experimental unit $\mathrm{Cg} 10$ ). For silicate-Si, concentrations oscillated between $257.794 \mu$ moles. $1^{-1}$ in the experimental unit $\mathrm{Cg} 40$ on the first day, and $11.536 \mu$ moles. $1^{-}$ 1 in the experimental unit $\mathrm{Cg} 30$ on the seventh day of experiment. The maximum concentration of phosphate-P was $29.281 \mu$ moles. $1^{-1}$ on the first day, and the minimum was $0.012 \mu$ moles. $1^{-}$ 1 on the seventh day.

In the experiments proposed in this study, the concentrations of nutrient salts (nitrite-N, nitrate- $\mathrm{N}$, silicate-Si, and phosphate-P) in some of the tested additions, were higher than the ones supplied by the nutritive medium $\mathrm{f}_{2}$ (Guillard, 1975), especially in the $20 \%, 30 \%$, and $40 \%$, although, this last medium supplied higher concentrations of nitrate. This fact, can have caused a higher microalgal production in the control enriched bioassays, as the assimilation of nitrogen by these is much greater that the rest of the nutrient salts.

The wastewater also presented high concentrations of silicate, mainly in the $30 \%$ and $40 \%$ additions, which rendered higher values to the ones obtained by the nutritive medium $f$. This also did not constitute a limiting factor for the growth of the tested diatoms during the bioassay.

The nutrient concentrations observed for the various experimental units tested, was higher than most values gathered by other authors, in respect to their use of alternative mediums: small dilutions of wastewater (YoneshigueBraga et al., 1977); organic extracts of the Macrocystis pyrifera macroalgae, of cattle and 
of chicken manure aerobically biodigested (Paniágua-Michel et al., 1987); chicken manure (Lacerda, 1988); mineralized and unmineralized syrup (Koening et al., 1988; 1990), among others.

\section{Population density and daily growth rate Chaetoceros gracilis}

The control bioassay enriched by the nutritive medium $f$, presented a minimum density of $26.25 \times 10^{3}$ cells $/ \mathrm{ml}$ on the first day, and a maximum of $6,760.00 \times 10^{3}$ cells $/ \mathrm{ml}$ on the eighth day of culture. For this bioassay the daily growth rates oscillated between 0.038 and 3,664 divisions/day.

For the bioassay treated with $30 \%$ wastewater, the minimum density registered was of $40.00 \mathrm{x}$ $10^{3}$ cells $/ \mathrm{ml}$ on the first day, while the maximum was of $3,535.00 \times 10^{3}$ cells $/ \mathrm{ml}$ on the ninth day of culture. The daily growth rates varied between 0.501 and 3.175 divisions/day.

In the highest concentration tested, that of $40 \%$ wastewater, a minimum density of $25.00 \times 10^{3}$ cells $/ \mathrm{ml}$ was observed on the first day, and a maximum of $4,125.00 \times 10^{3}$ cells $/ \mathrm{ml}$ on the ninth day of the experiment. The daily growth rates oscillated between 0.027 and 3.016 divisions/day (Table I).

When compared statistically to the significance level of $5 \% \quad(\mathrm{P}<0.05)$, significant differences were found between all the tested additions and the nutritive medium $f$. These differences were also registered when the various additions were compared between themselves (Table IIa).

\section{Thalassiosira sp}

The enriched control bioassay presented a minimum density of $8.75 \times 10^{3}$ cells $/ \mathrm{ml}$ on the first day, and a maximum of $876.25 \times 10^{3}$ cells $/ \mathrm{ml}$ on the twentieth day of the experiment. The daily growth rates oscillated between 0.353 and 2.362 divisions/day.

For the bioassay treated with $30 \%$ wastewater, respective minimum and maximum densities of $10.00 \times 10^{3}$ and $529.00 \times 10^{3}$ cells $/ \mathrm{ml}$ were observed on the first and ninth days. The daily growth rates oscillated between 0.004 and 2.852 divisions/day.
In the bioassay with $40 \%$ wastewater, a minimum population density of $8.75 \times 10^{3}$ cells $/ \mathrm{ml}$ was registered on the first day, while the maximum was registered with $834.00 \times 10^{3}$ cells $/ \mathrm{ml}$ on the fifth day. The daily growth rates for this bioassay oscillated between 0.391 and 2.947 divisions/day (Table I).

For this species, the statistical treatment showed similar results to the ones observed for Chaetoceros gracilis, i. e, all the comparisons demonstrated significant differences between the varying additions utilized in the experiment (Table IIb).

The data pertaining to the daily population densities obtained during the experiments for the two species can be seen in figures $1 \mathrm{a}$ and $1 \mathrm{~b}$.

Table I. Minimum and maximum populacional densities and growth rates of Chaetoceros gracilis and Thalassiosira sp obtained with different additions.

\begin{tabular}{|c|c|c|}
\hline & \multicolumn{2}{|c|}{ Chaetoceros gracilis } \\
\hline ADDITIONS & $\begin{array}{l}\text { POPULACIONAL } \\
\text { DENSITIES }\left(\times 10^{3}\right)\end{array}$ & $\begin{array}{c}\text { GROWTH } \\
\text { RATES }\left(\mathbf{x d}^{-1}\right)\end{array}$ \\
\hline F2 & $26.25^{*}-6,760.00^{* *}$ & $0.038 *-3.664 * *$ \\
\hline $\mathrm{Cg} 0$ & $33.50-2,060.00$ & $0.390 \quad-2.721$ \\
\hline $\mathrm{Cg} 10$ & $32,50-2,063.00$ & $0.037-3.016$ \\
\hline $\mathrm{Cg} 20$ & $31.25-2,995.00$ & $0.011-5.287$ \\
\hline $\mathrm{Cg} 30$ & $40.00-3,535.00$ & $0.501-3.175$ \\
\hline \multirow[t]{2}{*}{$\mathrm{Cg} 40$} & $25.00-4,125.00$ & $0.027-3.016$ \\
\hline & \multicolumn{2}{|c|}{ Thalassiosira $\mathrm{sp}$} \\
\hline ADDITIONS & $\begin{array}{l}\text { POPULACIONAL } \\
\text { DENSITIES }\left({\left.\mathrm{x} 10^{3}\right)}^{2}\right.\end{array}$ & $\begin{array}{l}\text { GROWTH } \\
\operatorname{RATES}\left(\mathrm{xd}^{-1}\right)\end{array}$ \\
\hline $\bar{F} 2$ & $8.75^{*}-876.00 * *$ & $0.353^{*}-2.362 * *$ \\
\hline Th0 & $15.00-123.00$ & $\begin{array}{ll}0.407 & -1.222\end{array}$ \\
\hline Th10 & $11.25-316.00$ & $1.874-2.662$ \\
\hline Th20 & $12.50-453.00$ & $0.501-2.291$ \\
\hline Th30 & $10.00-529.00$ & $0.004-2.852$ \\
\hline $\operatorname{Th} 40$ & $8.75-834.00$ & $\begin{array}{ll}0.391 & -2.947\end{array}$ \\
\hline
\end{tabular}

* Minimum values column / ** Maximum values column.

In terms of microalgal densities, the best results when compared with the bioassays provided with enrichments by the nutritive medium $f_{2}$ were registered in the bioassays $\mathrm{Cg} 40$ for Chaetoceros gracilis with $4,125 \times 10^{3}$ cells $/ \mathrm{ml}$ on the ninth day, and Th40 for Thalassiosira sp with $834 \times 10^{3}$ cells $/ \mathrm{ml}$ on the fifth day. For the 
daily growth rates, the best results were observed in $\mathrm{Cg} 20$ for $C$. gracilis with a value of 5.287 divisions/day between the first and second days. This fact doesn't necessarily imply a greater algal production, as the rates vary daily, thus it is the sum of the daily growth rates that determines a greater or lesser production. In this way, these rates serve only to point out the growth speed of the microalgae in culture.

Yamashita \& Magalhaes (1984), in a tentative to reduce the costs for the mass production of $C$. gracilis, used for the feeding of shrimp larvae (zoeae) of the species Penaeus brasiliensis, studied the use of four alternative mediums (B1, B-2, B-3 and B-4), developed from agricultural fertilizers. According to these authors, the medium B-1 (urea - 60mg/l, super-triplephosphate - 30mg/l and sodium silicate $15 \mathrm{mg} / \mathrm{l}$ ) was the one that rendered the highest algal density, reaching $6,415 \times 10^{3}$ cells $/ \mathrm{ml}$ on the sixteenth day of culture, which was higher than the value obtained by the conventional medium frequently used in the Institution. Although this value is higher than the one obtained by the wastewater for the culture of the same species $\left(4,125 \times 10^{3}\right.$ cells $\left./ \mathrm{ml}\right)$, this small difference doesn't represent, in practical levels, a greater or lesser efficiency of this medium, when compared to the agricultural fertilizer (medium B-1).

Table II. Non-linear values of the parameters of the mathematical model, used to carry out the statistical analisis $(\mathrm{P}<0.05)$ of the density data obtained for the species C. gracilis (a) and Thalassiosira sp (b).

\begin{tabular}{|c|c|c|c|}
\hline \multirow{3}{*}{$\begin{array}{c}\text { ADDITIONS } \\
(\%) \\
\end{array}$} & \multirow{2}{*}{\multicolumn{2}{|c|}{$\begin{array}{c}\text { MATH. MOD. } \\
\mathbf{n}^{\circ}=\beta_{0} . \text { t.e. } \\
\end{array}$}} & \multirow[t]{3}{*}{$\overline{\text { E.C }}$} \\
\hline & & & \\
\hline & $\beta_{0}$ & $\beta_{1}$ & \\
\hline Pure water & 144,062 & $-0,003$ & $a^{*}$ \\
\hline$f_{2}$ & 1428,152 & - 0,098 & $\mathrm{b}$ \\
\hline 10 & 372,519 & - 0,008 & $\mathrm{c}$ \\
\hline 20 & 599,670 & - 0,008 & $\mathrm{~d}$ \\
\hline 30 & 760,167 & - 0,009 & $\mathrm{e}$ \\
\hline 40 & 883,052 & - 0,009 & f \\
\hline
\end{tabular}

Table II (cont.)

\begin{tabular}{|c|c|c|c|}
\hline ADDITIONS & \multirow{2}{*}{\multicolumn{2}{|c|}{$\begin{array}{c}\text { MATH. MOD. } \\
\mathrm{n}^{\circ}=\beta_{0} \text {.t.e. }\end{array}$}} & E.C \\
\hline$(\%)$ & & & \\
\hline & $\beta_{0}$ & $\beta_{1}$ & \\
\hline Pure water & 28,273 & 0,126 & $\mathrm{a}^{*}$ \\
\hline$f_{2}$ & 144,951 & - 0,006 & b \\
\hline 10 & 59,972 & 0,008 & $\mathrm{c}$ \\
\hline 20 & 75,520 & 0,007 & d \\
\hline 30 & 126,514 & - 0,009 & e \\
\hline 40 & 175,792 & 0,009 & $\mathrm{f}$ \\
\hline
\end{tabular}

For Salas et al., (1992), when studying the effect of the microalgae Pavlova lutheri (Droop) Hibberd -cultivated with agricultural fertilizerson the growth and survival of Mytilus edulis (L) larvae, the cellular concentrations of approximatly $1.5 \times 10^{6}$ cells $/ \mathrm{ml}$ obtained were satisfactory. Besides giving an algal density comparable to many other mediums already tested, the author reenforces the necessity of further studies to search for more efficient mediums for algal production in relation to the maintenance of survival rates, larval and mollusk seed growth, and of other economically important organisms.

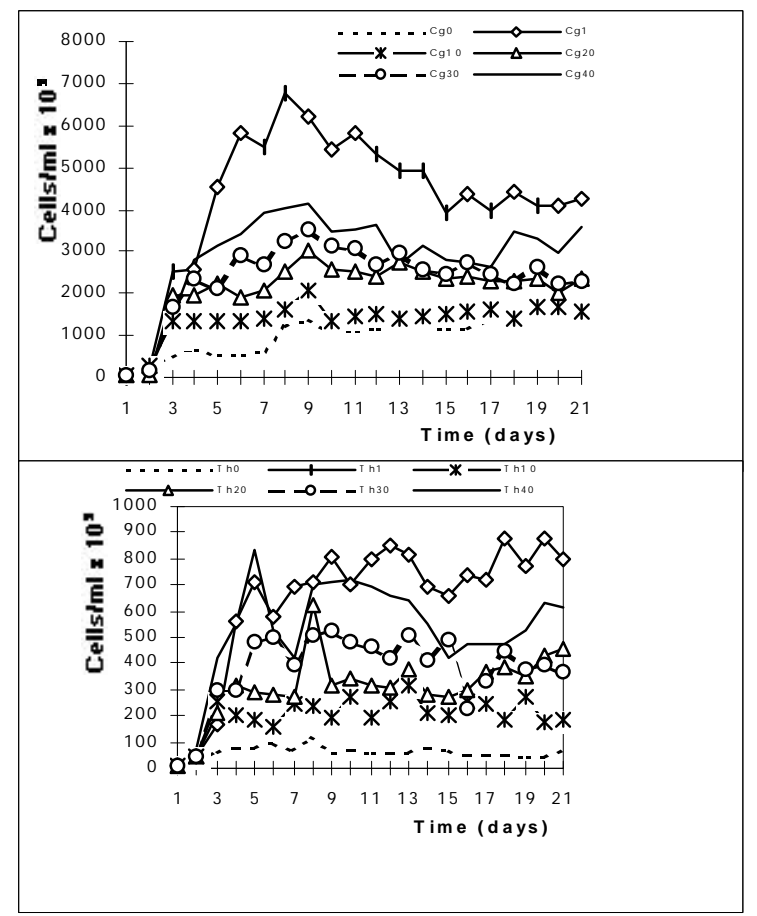

Figure 1. Daily population density (cells $/ \mathrm{ml}$ ) in the various additions used for the species Chaetoceros gracilis (a) and Thalassiosira sp (b) during the experimental period * Different letters between treatments, different parameters of the mathematical model. 


\section{Microalgal biomass (values of chlorophyll-a) Chaetoceros gracilis}

The control bioassay enriched with the nutritive medium $\mathrm{f}_{2}$ presented minimum and maximum values of $0.061 \mu \mathrm{g} / \mathrm{ml}$ on the first day, and $2,363 \mu \mathrm{g} / \mathrm{ml}$ on the ninth day. The minimum concentration registered for the bioassay submited to the treatment of $30 \%$ wastewater was of $0.052 \mu \mathrm{g} / \mathrm{ml}$ on the first day, and maximum of $0.76 \mu \mathrm{g} / \mathrm{ml}$ on the fifth day.

In the bioassay treated with $40 \%$ wastewater, the minimum and maximum values were $0.052 \mu \mathrm{g} / \mathrm{ml}$ on the first day and $0.768 \mu \mathrm{g} / \mathrm{ml}$ on the fifth day, respectively.

For this species, the additions that demonstrated results considered statistically the same, were those of $30 \%$ and $40 \%$, the rest of the additions being considered statistically different between themselves (Table IIIa).

\section{Thalassiosira sp}

The enriched control bioassay, presented minimum and maximum values of 0.051 and $2,152 \mu \mathrm{g} / \mathrm{m}$, on the first and ninth days, respectively The minimum and maximum concentrations observed in the experimental unit treated with $30 \%$ wastewater were 0.066 and $1,156 \mu \mathrm{g} / \mathrm{ml}$, on the first and thirteenth days, respectively In the experimental unit treated with $40 \%$ wastewater, the minimum and maximum values were 0.078 on the first day and $0.883 \mu \mathrm{g} / \mathrm{ml}$ on the thirteenth day, respectively.

For Thalassiosira sp, the comparisons of the biomass data demonstrated significant differences between all the tested additions ( Table IIIb). All the values obtained for the species Chaetoceros gracilis and Thalassiosira $\mathrm{sp}$ during the experiments are in figures $2 \mathrm{a}$ and $2 b$.

In relation to biomass, which is another important factor for the choosing of a particular culture medium, the more representative results were the ones treated with $40 \%$ and $30 \%$ wastewater. These treatments, present maximum chlorophyll- $a$ values of $0.768 \mu \mathrm{g} / \mathrm{ml}$ for the species Chaetoceros gracilis (fifth day), and $1,156 \mu \mathrm{g} / \mathrm{ml}$ for Thalassiosira $\mathrm{sp}$, on the thirteenth day of the experiment.
The treatment with $40 \%$ wastewater, for Chaetoceros gracilis, rendered the highest values of population density and microalgal biomass, having the best results in terms of microalgal production. For Thalassiosira sp, the highest population density was also registered in the $40 \%$ addition, while the biomass presented a maximum value in the treatment of $30 \%$ wastewater.

The maximum chlorophyll- $a$ values observed by Koening et al., (1988), when cultivating Tetraselmis chuii submited to a treatment with $0.66 \%$ mineralized syrup, diluted at 50 and $25 \%$ (158 and $148.05 \mathrm{mg} / \mathrm{m}^{3}$ ), were inferior to the values registered for the additions of $40 \%$, $(0.768$ and $0,883 \mu \mathrm{g} / \mathrm{ml})$ for Chaetoceros gracilis and Thalassiosira sp., respectively Also, by using extract of chicken manure for the culture of the same species, a maximum microalgal biomass of $332.50 \mathrm{mg} / \mathrm{m}^{3}$ was observed, which is a lower value to the obtained by the wastewater. The maximum concentration of chlorophyll- $a$ registered by these authors in the culture of Dunaliella tertiolecta $(1,492.60$ $\mathrm{mg} / \mathrm{m}^{3}$ ) with chicken manure, was higher to the obtained by the wastewater in the culture of the two species used in the study. For Tetraselmis chuii as well as for Dunaliella viridis, the highest results were those with the addition of $10 \mathrm{ml}$ of chicken manure extract.

The values referred above for Tetraselmis chuii were lower to the ones obtained by Koening et al., (1990), which by using an addition of $30 \mathrm{ml}$ of chicken manure extract in the culture of the same species, obtained a biomass of $1,003.88$ $\mathrm{mg} / \mathrm{m}^{3}$ on the eighth day of the experiment. This value was still surpassed by the experimental unit Th30. The biomass registered by the same authors for Tetraselmis tetrathele, was of $2,014.16 \mathrm{mg} / \mathrm{m}^{3}$ on the ninth day, which was a higher value than any of the additions tested with wastewater.

None of the treatments were statistically the same to the results obtained by the nutritive medium $f_{2}$ (Guillard, 1975). But, for these species, it is possible to conclude that the efficiency, the low cost and the facility of obtaining wastewater, when compared with other alternative mediums, can, after tests in large scale, come to reduce considerably the costs of microalgal production. 
Table III. Non-linear values of the parameters of the mathematical model, used to carry out the statistical analisis $(\mathrm{P}<0.05)$ of the biomass data obtained for the species C. gracilis (a) and Thalassiosira sp (b).

\begin{tabular}{|c|c|c|c|}
\hline \multirow{3}{*}{$\begin{array}{c}\text { ADDITIONS } \\
(\%) \\
\end{array}$} & \multirow{2}{*}{\multicolumn{2}{|c|}{$\begin{array}{c}\text { MATH. MOD. } \\
n^{\circ}=\beta_{0} . \text { t. } \mathrm{e}^{\beta 1 . t}\end{array}$}} & \multirow[t]{2}{*}{ E.C } \\
\hline & & & \\
\hline & $\beta_{0}$ & $\beta_{1}$ & \\
\hline Pure water & 0,006 & $-0,121$ & $a^{*}$ \\
\hline$f_{2}$ & 0,809 & - 0,130 & $\mathrm{~b}$ \\
\hline 10 & 0,109 & - 0,143 & $\mathrm{c}$ \\
\hline 20 & 0,144 & - 0,129 & d \\
\hline 30 & 0,255 & - 0,129 & $\mathrm{e}$ \\
\hline 40 & 0,243 & - 0,128 & $\mathrm{f}$ \\
\hline
\end{tabular}

\begin{tabular}{|c|c|c|c|}
\hline \multirow{3}{*}{$\begin{array}{c}\text { ADDITONS } \\
(\%) \\
\end{array}$} & \multirow{2}{*}{\multicolumn{2}{|c|}{$\begin{array}{c}\text { MATH. MOD. } \\
\mathbf{n}^{\circ}=\beta_{0} \cdot \text { t. } e^{. \beta 1 . t}\end{array}$}} & \multirow[t]{3}{*}{ E.C } \\
\hline & & & \\
\hline & $\beta_{0}$ & $\beta_{1}$ & \\
\hline Pure water & 0,005 & - 0,122 & $a^{*}$ \\
\hline$f_{2}$ & 0,738 & - 0,132 & b \\
\hline 10 & 0,105 & - 0,108 & $\mathrm{c}$ \\
\hline 20 & 0,161 & - 0,106 & d \\
\hline 30 & 0,315 & - 0,119 & $\mathrm{e}$ \\
\hline 40 & 0,216 & - 0,093 & $\mathrm{f}$ \\
\hline
\end{tabular}

${ }^{*}$ Different letters between treatments, different parameters of the mathematical model
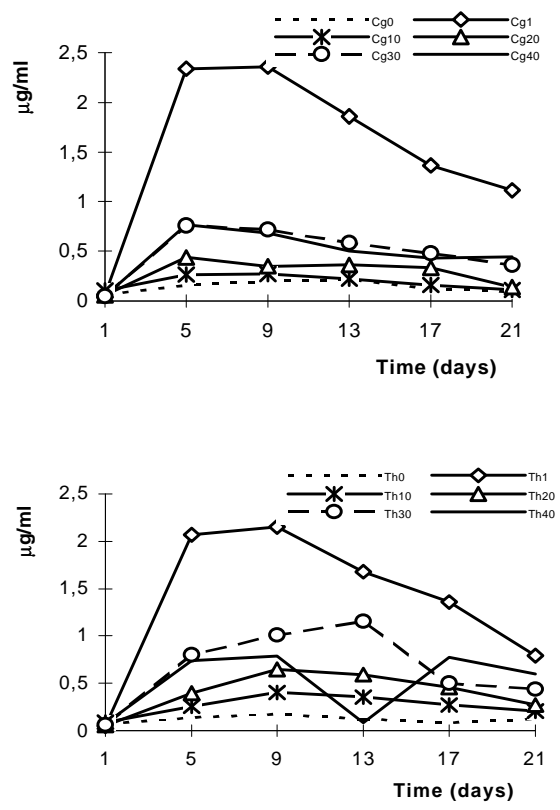

Figure 2. Microalgal biomass (values of chlorophylla) of the various experimental unit tested for the species Chaetoceros gracilis (a) and Thalassiosira sp.(b) during the experimental period.

\section{ACKNOWLEGMENTS}

Thanks are given to the National Counsel of Scientific and Technological Development $(\mathrm{CNPq})$, which through the concession of a Masters scholarship made this project possible, and to the Oceanography Department of the Federal University of Pernambuco for the disponibility of their laboratories along the course of the experiments, and contribution to the necessary analisis for the completion of the study.

\section{REFERENCES}

Brasil-Lima,G. M. S. S., Aidar, E. Avaliação do efeito do esgoto doméstico sobre o crescimento de Phaeodactylum tricornutum, em bioensaios algais. In: REUNIÃO BRASILEIRA DE FICOLOGIA, 7.,1996, Caxambu,1996, p. 76

Creitz, G.I., Richards, F. A. The estimation and caracterization of the plankton populations by pigments analyses. III. A note of the use of millipore membrane filters in the estimation of plankton pigments. Journal of Marine Research, New Haven, v. 14, n. 3, p. 211-216,1955.

Dustan, W. M., Menzel, D.W. Continuous cultures of natural populations of phytoplankton in dilute sewage effluent. Limnology and Oceanography, Lawrence, v. 16, n. 4, p. 623-632, 1971.

Dustan, W. M., Tenore, K. R. Intensive outdoor culture of marine phytoplankton enriched with treated sewage effluent. Aquaculture, Amsterdam, v. 1, n. 2, p. 181-192, 1972.

Goldman, J. C., Stanley, H. I. Relative growth of different species of marine algae in wastewatersea water mixtures. Marine Biology, Heidelberg, v. 28, n. 1, p. 17-25, 1974.

Grasshoff, K, Emrhardt, M., Kremling, K. Methods of seawater analysis. 2. ed. New York: Verlag Chemie, 1983. 419p.

Guillard, R. R. L. Division rates. In: Stein, J. R. Handbook of Phycological Methods - Culture methods and measurements. Cambridge University Press, 1973. p. 289-313.

Guillard, R. R. L. Culture of phytoplankton for feeding marine invertebrates. In: SMITH, W. L., CHARLEY, M. M. Culture of marine invertetebrates animals. New York: Plenum, 1975, p.29-60.

Koening, M. L. et al. O vinhoto no cultivo de microalgas. Gayana Bot., Concepción, v. 45, n.1/4, p. 253-263, 1988.

Koening, M. L. et al. Cultivo em laboratório de Tetraselmis chuii e Tetraselmis tetrathele (Chlorophyceae) com fertilizante orgânico. Arquivos de Biologia e Tecnologia, Curitiba, v. 33, n. 1, 1990. 
Lacerda, S. R. Cultivo em laboratório de Tetraselmis chuii e Tetraselmis tetrathele (Chlorophyceae) com fertilizante orgânico; Recife, 1988. Monografia apresentada ao Curso de Ciências Biológicas da Universidade Federal Rural de Pernambuco.

Paniagua-Michel, J., Farfan, B. C., Buckle-Ramirez, F. Culture of marine microalgae with biodigested resources. Aquaculture, Amsterdam, v. 64 n. 3, p. 249-256, 1987.

Parsons, T. R., Strickland, J. D. H. Discussion of spectrophotometric determination of marine plankton pigments with revised equations of as certaining chlorophyll- $a$ and carotenoids. Journal of Marine Research, New Haven, v. 21, n. 3, p. 155-163,1963.

Salas, L. S. Mca., Aranda, F. J. O., Pámanes, L. E. G. Efecto de la microalga Pavlova lutheri (Droop) Hibberd cultivada con fertilizantes agricolas en el crescimiento y supervivencia de larvas y postlarvas del mejillon Mytilus edulis (L.). Ciencias Marinas, México, v. 18, n. 4, p. 57-74, 1992.

Santos, E. P. Ajustamento de curvas: Programa Computacional "CAJUS", 1995.
Strickland, J. D. H., Parsons, T. R. A manual of sea water analysis. Bulletin Fisheries Reasearch Board Of Canada, Ottawa, v. 125, p. 1-205, 1972.

Taslakian, M. J., Hardy, J. T. Seawage nutrient enrichment and phytoplankton ecology along the central coast of Lebanon. Marine Biology, Heidelberg, v. 38, n. 4, p. 315-325, 1976.

UNESCO. Determination of photosynthethic pigments in sea waters. Raport of SCOR/UNESCO, Working group 17 with meet from 4 to 6 june 1964. Paris, 1966. (Monographys on Oceanography Methodology, n. 1). 69p.

Yamashita, C., Magalhães, P. M. S. Meios de cultura para a alga Chaetoceros gracilis. Natal (RN). EMPARN, 1984. 18 p. (Boletim de Pesquisa, 7).

Yoneshigue-Braga, Y. et al. A preliminary study using untreated municipal sewage as a basic algal culture media. Publ. Inst. Pesq. Mar., n. 105, p. $1-6,1977$. 
